Jurnal The Messenger, Vol. 10, No. 1, January 2018, pp. 24-33

P-ISSN: 2086-1559, E-ISSN: 2527-2810

DOI: $10.26623 /$ themessenger.v10i1.653

\title{
Communication Strategy Based on Islam Value of U-Jek Online Taxibike (Ojek) in Semarang
}

\section{Strategi Komunikasi Berbasis Nilai Islam Ojek Online U-Jek di Semarang}

\author{
Mubarok $^{1}$ \\ ${ }^{1}$ Study Program of Communication Science, Universitas Islam Sultan Agung Semarang, \\ Jl. Kaligawe Raya Km. 4, Terboyo Kulon, Genuk, Semarang 50112, Indonesia \\ *e-mail: mubarok@unissula.ac.id
}

\begin{abstract}
U-Jek was developed by Zarkasyi, in Unissula Semarang. This study aims to explain the communication strategy to develop an online taxibike (ojek) value-based Islam. This research strategy is descriptive qualitative research. Through this strategy, researchers want to know the current condition of U-Jek, 'ojek' in Semarang. Researchers will explain the development of student 'ojek' in Semarang, researchers also eager to analyze the using of communication strategy, and to formulate the right strategy to develop student 'ojek' in Semarang. The researcher also elaborates U-Jek's communication strategy and reveals its advantages and disadvantages. The results that the biggest challenge of U-Jek communication strategy is the commitment of its managers. U-Jek Manager must increase its communication channel capacity by developing digital application service. In the pyramid communication plan, U-Jek's manager does not pay attention to the aspect of the framework of issues which become message base.
\end{abstract}

Keywords: Islamic Value, Ojek (Taxibike/Motorcycle Taxi), Student, Communication Strategy.

\begin{abstract}
Abstrak
U-Jek dikembangkan oleh Zarkasyi, di Kampus Unissula Semarang. Penelitian ini bertujuan untuk menjelaskan strategi komunikasi untuk mengembangkan ojek online berbasis nilai Islam. Strategi penelitian ini adalah penelitian deskriptif kualitatif. Melalui strategi ini peneliti ingin mengetahui keadaan sekarang tentang ojek online U-Jek di Semarang. Peneliti akan memaparkan perkembangan ojek online mahasiswa di Semarang, menganalisa strategi komunikasi yang digunakan, kemudian merumuskan strategi yang tepat untuk mengembangkan ojek online mahasiswa di Semarang. Peneliti juga menguraikan strategi komunikasi yang telah dilakukan oleh U-Jek dan mengungkapkan kelebihan dan kekuranganya. Hasil penelitian menunjukkan tantangan terbesar dari strategi komunikasi U-Jek adalah komitmen dari para pengelolanya. Pengelola U-Jek harus meningkatkan kapasitas saluran komunikasinya dengan mengembangkan layanan aplikasi digital. Dalam communication plan pyramid, pengelola UJek tidak memperhatikan aspek kerangka isu yang menjadi landasan pesan.
\end{abstract}

Kata Kunci: Nilai Islam, Ojek, Mahasiswa, Strategi Komunikasi.

Copyright (C) 2018 Universitas Semarang. All rights reserved.

\section{Introduction}

U-Jek is student online taxibike (ojek) developed in Semarang. This business was initiated by Zarkasyi, a student of Unissula Semarang. U-Jek is an abbreviation of Unissula Ojek which was founded with differentiation strategy namely Islamic value based online ojek. U-Jek birth was inspired by the rise of online motorcycle taxis phenomena in Indonesia. Consumer acceptance of online motorcycle taxis shows that

Article History: Received October 31, 2017; Revised January 19, 2018; Accepted January 27, 2018; Published January 31, 2018 
this business prospect will grow and become the main transportation service in the world. To distinguish the presence of U-Jek and the online motorcycle taxi that had already been present in the city of Semarang, Zarkasyi added Islamic values as the service base and the communication strategy.

Communication strategy is usually done in public relations activities and marketing communications. Public relations and marketing are fields that often collide. Public relations is management function that focuses on long-term interaction between the organization and the public related to the organization to obtain goodwill, mutual understanding and support. Marketing communication is function in management that focuses attention on products or services to meet the wants and the needs of consumers. Coordination of the two activities can improve the efficiency and effectiveness of an organization and is known as integrated marketing communication (IMC). Philip Kotler provides four stages of the process in marketing communications i.e environmental analysis, public identification and objectives, developing strategic approaches and developing implementation plans. Smith provides nine phases that are grouped into four phases in the preparation of strategic communications for public relations namely formative research, strategy, tactic and evaluation research (Pudjosantosa, 2010: 7).

To make a difference at the same time become the superiority of service, U-Jek uses the Islamic values base. U-Jek itself is not the only student online taxibike (ojek) which grow up in Semarang city. In some other campuses in Semarang city also develop student online taxibike (ojek). The presence of an Islamic value-based U-jek is interesting to examine the communication strategies developed to compete with other online motorcycle taxis. The Islamic values characteristics made differentiation by $\mathrm{U}$ Jek is an interesting differentiation to the other concepts. This study aims to explain the appropriate communication strategy for U-Jek to develop student online taxibike (ojek) based on Islamic values in Semarang. The aspects to be discussed in order to achieve these objectives are (1) what are the advantages and disadvantages of communication strategies that have been used by online taxibike (ojek) operators in Semarang (2) how the student online taxibike (ojek) management practices that have been conducted (3) how to formulate appropriate communication strategies based on the potential of advantages and challenges faced.

\section{Methodology}

The function of paradigm as a set of beliefs or basic belief systems that direct the actions of researchers, related to the main principles (principal). The paradigm of this research is an interpretive paradigm that is different from other paradigms in terms of epistimology, ontology, axiology, and methodology (Guba and Lincoln 2005: 99).

This research strategy is qualitative descriptive research. Through this strategy researchers want to know the current condition of U-Jek as an student online taxibike (ojek) based on islamic value in Semarang. Researchers will describe the development of U-Jek, to analyze the using of communication strategy, and formulate the right strategy to develop its business in Semarang.

Data collection techniques are conducted by in-depth interview and dialogue. Respondents in this study amounted to 10 people representing the management U-Jek, lecturers, students and employees in the environment Unissula Semarang. Interviews were conducted with the administrator of student online taxibike, students online ojek users and testimonials from several lecturers who know the activities of student online.

Jurnal The Messenger, Vol. 10, No. 1, January 2018, pp. 24-33 
Interviews with managers are conducted to determine the born of online ojek, implementation management, and the developing communication strategies. Interviews with users are conducted to gain real experience during to use student online taxibike (ojek). To complete the data of the interview result, the two researchers are conducted field observation to know the reality of student online taxibike (ojek). Third, the researcher did observation of the web site and social media which was used by the student online.

Data analysis phase is conducted by using strategic compilation phase analysis which includes formative research, strategy, tactic and evaluation research (Pudjosantosa, 2010). The analysis of the formative research stage is conducted by situational analysis, organizational analysis, and public analysis. Situation analysis is a statement about the opportunities and obstacles faced by the communication program. Organizational analysis: covering aspects of the internal environment, public perceptions and the external environment include competitors and supporters.

Public analysis is the identification and public analysis, as the key of different groups of people interacting with organization. Strategy analysis has two focuses, they are the actions are conducted by organization and the message content. Tactical analysis consists of the selection of communication tactics used and the implementation of the strategic plan that has been prepared. In the last phase is to evaluate and to determine the effectiveness of various communication tactics used to achieve goals and target that have been determined. This study has several limitations, they are: time constraints so that researchers can not be interviewed all student online taxibike (ojek) drivers. Researchers can not conduct dialogic validity (Saukko, 2003: 11) which provides an opportunity for the subject to give comment on the results of this study.

\section{Result and Discussion}

U-Jek was founded in February 2016 by Zarkasyi a student of Communication Program of Unissula Semarang. The main reason for the establishment of the taxibike (ojek) is based on Zarkasi's personal experience which often finds difficulty in finding public transportation to support his learning activities. Based on his personal experience, Zarkasi conducted a survey to ascertain whether student onlien taxibike can be developed on this campus. The presence of U-Jek is welcomed by students and lecturers at Unissula campus warmly. The average driver can earn between 1,800,0003,000,000 per month (Data from Interviews June 2016).

Based on the description of the table, the biggest challenge from the communication strategy of online student taxibike (ojek) is the commitment from the managers. The potential and support they get should be able to make their business develope and grow. In communication strategy the biggest challenge is internal commitment that must be strong and confident. The results of interviews with Zarkasi (manager of U-Jek) said that the market potential is very large it is the manager who is not ready to develop the business. For example he reveals the attitude of inconsistent drivers. After joining and ready to work with professionality, they can not bring customers for various reasons. This makes customer's trust decreased. This issue of consistency become obstacle to the management.

To promote the services, social media and messenger becomes a powerful tool, while the website is not very interested in the customer. One of the fundamental shortcomings is the unavailability of digital app services from each student online taxibike (ojek) manager like Gojek which is available on Playstore and Appstore. This 
deficiency makes the level of customer's trust to be reduced. Consumers still think that managers are not serious. According to Zarkasi, U-Jek's service which is pioneered by him has started to create applications but are constrained by the ability to create information systems and funding constraints so they choose to use Line Apps system, Whatsappp and BBM services.

The weakness of this service according to Zarkasi is the lack of consumer penetration because they have to join first in the messenger service. Consumers also do not want the personal profile in their messeger are known by others. The neccesity to ojek online is limited to the service transactions and do not want to grow further. Therefore, digital app services are more attractive than messenger services.

From the description it appears that online motorcycle taxi drivers should increase their communication channel capacity by developing digital application services. They cannot rely on short messging service anymore. This digital application is important to increase the confidence and reach market penetration.

Here is a Communication Pyramid that includes 6 steps:

1. Identify Communications Infrastructure; 2. Setting Goals; 3. Target Activities; 4. Determining the Target Audience; 5. Framing the Issue; 6. Message

The six steps will be used to analyze U-Jek's strategy as an online student taxibike that carries Syariah value.

1. Identify Communications Infrastructure

Online taxibike (ojek) business with student market has a special characteristic. First they are a young and familiar consumer with communication technology. Second, decision-making is strongly influenced by the community. They put forward the flexibility and speed of response. In their hands there are sophisticated device that can access information as well as capable of being used as a communication tool with various platforms. They can search information, compare prices and make decisions with communal-based social media. So the realistic option is to utilize the inherent infrastructure. U-Jek managers do not use top-line communications tools but instead promote community approaches that promote products, capture consumers and add new value to their business.

2. Define Goals

The value-add provided by U-jek compared to other online transport is the value of sharia. Other online taxibike (ojek) emphasizes speed, affordability, security and comfort in service. While Islamic values have not been to be a major consideration. UJek consumers want that when they take advantage of this transportation, they can be served according to Islamic sharia principles. They want women consumers to be served by female drivers and vice versa. These values simultaneously convince the manager that the differentiation of sharia values can be accepted by consumers. Zarkasyi as founder and manager revealed some key principles of his business which later became the principle of the developed communication strategy.

2.1. U-Jek is not intended merely for profit but as a means of practicing and growing entrepreneurial spirit among Unissula Semarang students. Therefore Zarkasyi as the founder since the beginning tried to invite various communities on campus to develop this business. He also did regeneration so that someday anyone can continue this business. After graduate he did not want to continue to manage this business but to pass on to the next generation as an entrepreneurship training ground.

2.2. Enterprises with a view to preaching Islamic values. Zarkasyi said that the efforts developed must be able as a media to disseminate and introduce Islamic values which is

Jurnal The Messenger, Vol. 10, No. 1, January 2018, pp. 24-33 
to be hold and believed. Therefore every part of U-Jek must understand that their main efforts are not to run for profit but togetherness and da'wah of religious values.

Based on the two main goals of U-Jek, the messages made by the manager will lead to that goal.

3. Activities Target

In the first year, U-Jek's business is targeted to make its existence known to all academic community in Unissula Semarang. Therefore, in the year 2016 managers quite incentive to disseminate to all people on campus. Beside social media utilized by their managers, they are also active by attending campus community events both conducted at the university level, faculty and even discussion forums conducted by students. The target of the activity is to increase awareness of the campus academic community about U-Jek's existence. In 2017 Zarkasyi targeted to be graduated from college so before it happen, He should regenerate the U-jek to his junior. From the process of establishing until the graduation there are two major targets of activity proclaimed by U-Jek. The first is to introduce businesses to all campus academic community as well as establish business operations ranging from management, drivers, communication network and start-up application development for U-Jek services. The second prepares for regeneration of management considering the founder's graduation target in 2017. The regeneration process requires greater energy because the business is not yet stable and still requires the intervention of the founders while the founders targeting in 2017 should have hand over the management.

4. Audience Target

Stakeholders of this first venture is campus academic community includes lecturers, employees, and students. They can be consumers, business partners, managers as well as advisors of this business. Therefore the main communication strategy undertaken focuses on them. Several lecturers and students who have enjoyed U-Jek's service are asked to provide testimony as well as provide input and critique of this business. they advise to include Islamic sharia values. Second, managers of similar businesses that can be a competitor as well as partners.

5. Framing the issue

The main issues framed in their communication strategy are joint efforts, blessings and not just cheap. They emphasize that business is not just for profit but as a propagation field as well as a media of practicing entrepreneurship among students.

6. Message

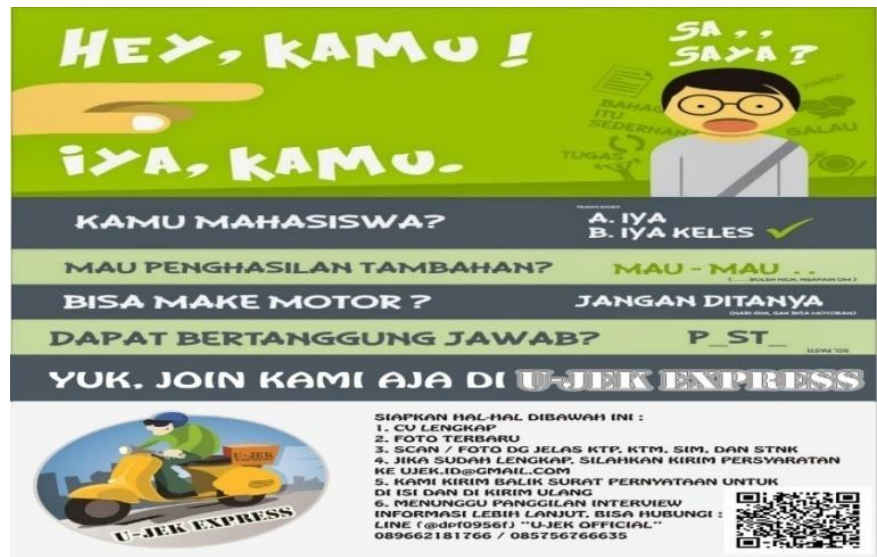

Figure 1. Driver Recruitment Message

The message put forward by U-Jek managers not only focuses on efforts to promote product or to convince U-Jek customers. One of the most important messages they 
convey is the effort to find partners for this business. The driver plays an important role in the continuity of this business so that recruitment should always be done.

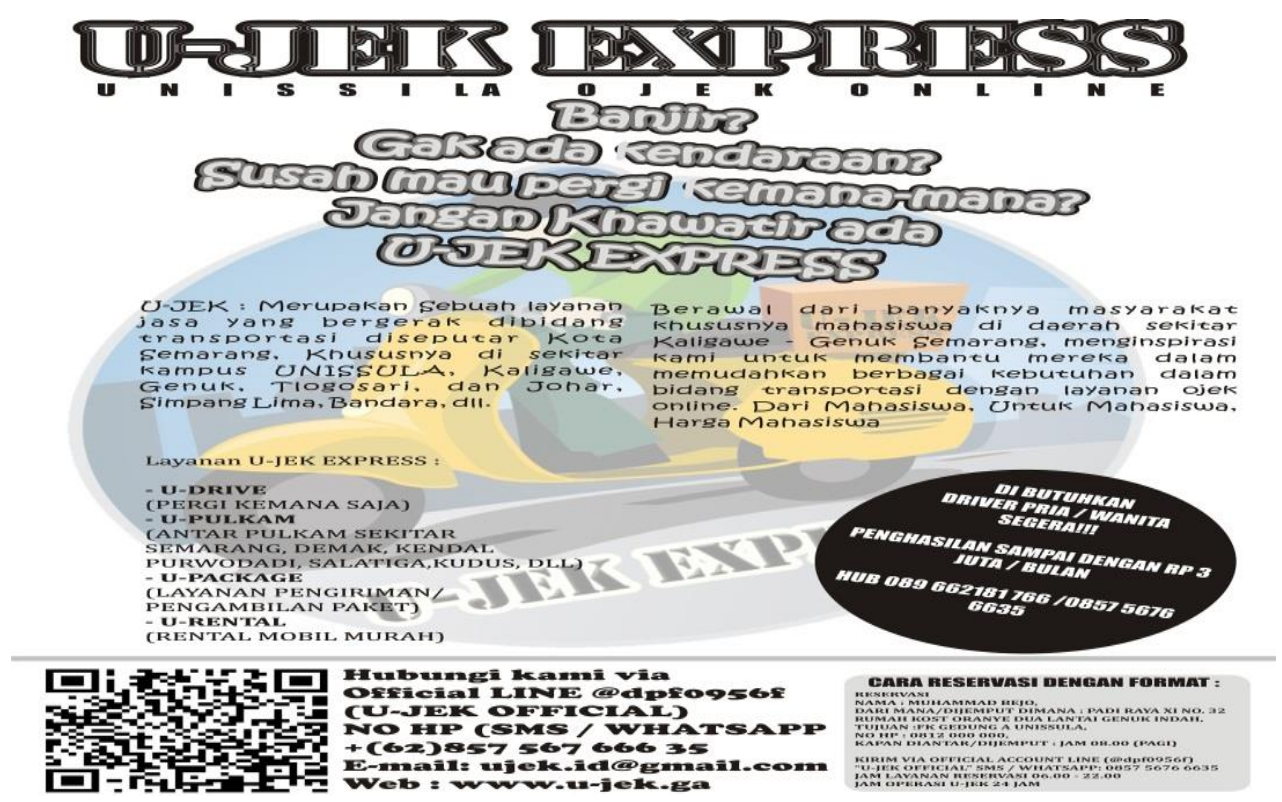

Figure 2. Messages To Attract Customers

In addition to the recruitment, the message conveyed by U-Jek is related to the prompt service and the flood problem that emerge in the message material. Unissula student boarding areas around Genuk (Semarang) is flood-prone spot. The service messages associated with the conditions faced by consumers as if to remind the importance of transport presence to overcome their problems. Both messages have not touched the aspect of shariah services from U-Jek. A new syariah ojek service message appears in the following leaflets:

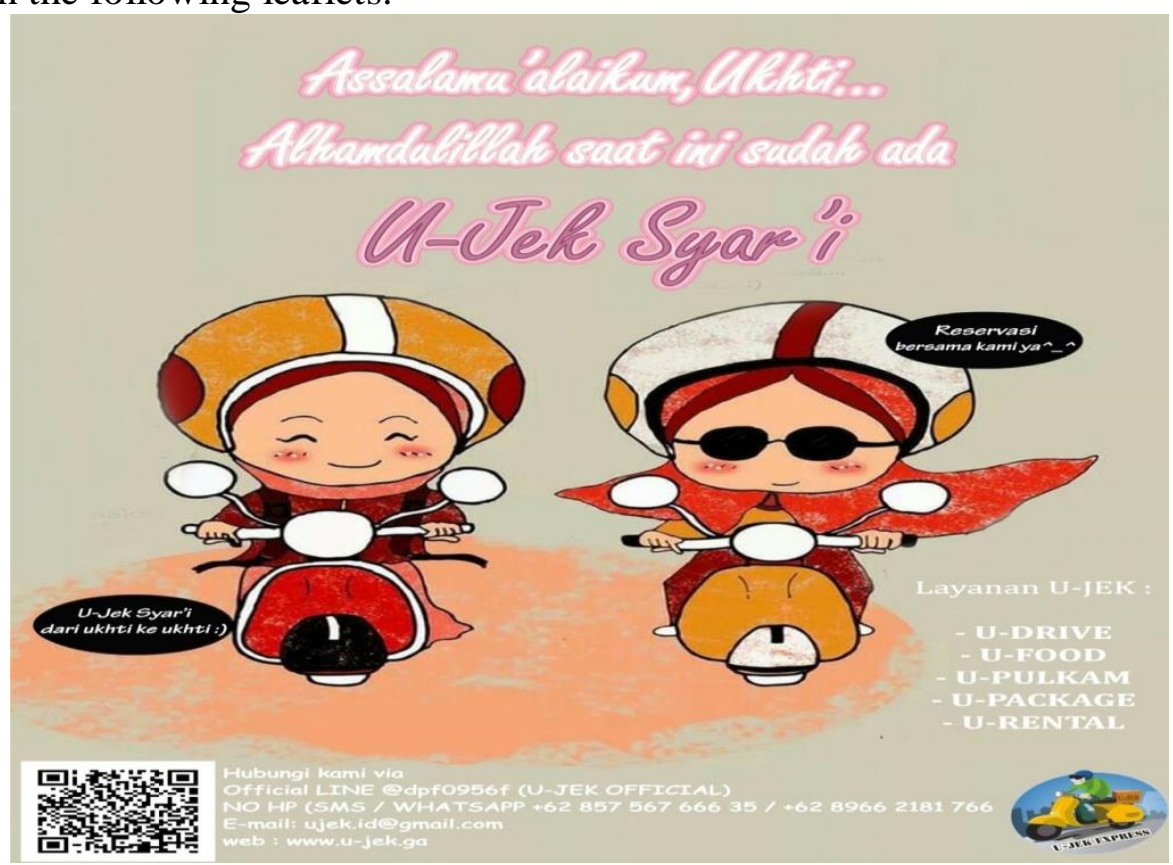

Figure 3. Messages to Attract Customers 
The message of student online taxibike (ojek) service based on syariah values comes after getting input from the consumer. This means that this new vision comes after getting input from consumers.

Efforts to achieve the goal of effective communication need to be enhanced in order for U-Jek to develop according to the specified target. Here are the elements of effective Communication:

There are three types of effective ways of communication that can be reached, they are : 1. Publicity of mass media to organizations, people, products, and services to support idea. By stating that the activities undertaken are opened and observable to gain understanding and support of the organization. Once the strategy of action and response is formulated, effective communication mechanism is also to be formulated. Things to note in the formulation of an effective message is a communicator who will convey the message. The approach is used in composing the message. The message structure includes the words and symbols that will be used. The communication model used in communication planning is an informative, persuasive and dialogue model to gain mutual understanding.

2. Using third party endosers that have high credibility. Spoke person used is functioned to several company spokes person including Director, Directorate of Promotion, Cooperation, Public Relations. From outside of the organization, we can asked the assistance from community leaders, government officials and other parties who has high competence.

3. Newsworthy information to gain attention from the media and the public using the principles of significance, localness, balance, and timeliness plus unussualness and fame shortened to SiLoBaTi + UnFa and transparent communication.

The following are descriptions of the three elements of effective communication:

1. Media Publicity to Organizations, People and Products

U-Jek does not have to do publication using its own media but cooperation with media in various forms. It is important that the media is willing to publish organizational activities, people and products. Media publicity to the organization relates to U-Jek institutionally. Managers can come to participate in various activities inside or outside campus. From various activities the manager can bring the name of UJek as well as introduce the organization. For example on the campus quite a lot of community media that is managed by faculty, units, and student activity unit (UKM Kemahasiswaan). This media has a specific audience target so that makes it easy to reach the target U-Jek consumer. Managers can be present as a speaker or institutionally supports an activity so that U-Jek's products and brand will become well known in the campus.

2. Using Third Party Endoser

U-Jek can ask for help from various parties who have high credibility to support the promotion. Company spokes person can come from lecturer, or university leader so that credibility and trust from other side to U-Jek will increase. Managers can also request user testimonials about the services they have provided so as to increase user trust.

Unissula Semarang wants the growth of young entrepreneurs from the campus so that the existence of creative business like U-Jek will get full support. Some of the parties who can help become Company spoke person from the structural is Bureau of Student and Alumni. They can be asked to comment as well as provide input for the development of U-Jek. If possible in various events that followed by campus leaders 
such as Head of study program (Kaprodi), Dean or even Rector can be alluded to the creative process of this student so that will increase public confidence.

From outside the campus there are institutions such as creative agencies are run by ministries and they are actively growing creative endeavors. They will be happy to assist business promotion.

3. SiLoBaTi + UnFa and Transparent Communication

Messages that receive media attention are messages that meet news value criteria. Briefly formulated in the principle of significance, localness, balance, timeliness plus unussualness and fame.

The message that is made must have an important value for all U-Jek stakeholders. Messages should be able to demonstrate the importance of U-Jek's presence to all concerned parties. This principle can only be done on messages related to product promotion and driver recruitment.

U-Jek says:

Flood?

No vehicles?

Hard to go anywhere?

Do not worry there is U-Jek Express

The Message above has important value for U-Jek users, lecturers, students and potential customers. While the message locality aspect has not been included in the message. U-Jek's customers are in Genuk area, and Semarang City so that the message of locality is very important. The messages used by U-Jek have not yet been touched the aspect of the locality. Managers can add aspects such locality for example:

Genuk, Genuk Indah, Kaligawe are swept by floods?

Do not be afraid, there is U-Jek ready to take you everywhere?

To make a difference from a competitor so that U-Jek must create an unusual message, using language and different communication media. This means that managers must be creative to create messages and different media from competitors.

One of the media that can be reached is community event. This event can be followed to deliver the message while strengthening the brand. The student community has many events and can be utilized as an effective communication medium.

U-Jek has devised a communication strategy by utilizing available facilities and communication infrastructure. In outline will be described the advantages and disadvantages of the strategy that has been used.

Advantages:

1. U-Jek has used the latest communication device. This means they are not trying to use conventional media and choose a medium that is familiar to their potential customers. Managers use social media like Line, Twitter, Google Plus, Facebook, WhatsApp. Managers also take advantage of websites with blogspot platform. Website address $\mathrm{u}$-jek.blogspot.com is used to display information from managers, products and consumer services.

2. U-Jek managers use Mouth World Strategy to provide information to consumers. They take advantage of testimonials given by users to conduct persuasion to potential customers

3. U-Jek has potential customers on campus. Unissula has fifteen thousand students. for minimum. With the availability of ten percent of them being U-Jek's customers there are 1500 potential students to be targeted.

Jurnal The Messenger, Vol. 10, No. 1, January 2018, pp. 24-33 
4. Location Proximity, emotion and other primordial factors as a form of Unissula students become capital to managers for consumers' benefit. Emotional superiority and primordial factors must be managed properly by the manager to contribute benefits for U-Jek.

Deficiency:

1. Managers' Consistency becomes the biggest problem. They are not consistent in managing messages, managing human resources so that U-Jek performance is not maximal. It appears that the founder works alone and unable to delegate the work to other administrator. The task division on the team is not clearly described so that the role of each personnel is not obvious. Another consistency issue is the consistency of service from the driver. Without consistency from the driver it would be difficult for UJek to provide excellent service. U-Jek should increase the number of drivers so as to reach more customers while providing consistent service. So far, customers are not given good service, due to the absence of driver. The number of permanent drivers only five people, makes it difficult for managers to provide excellent service. Recruitment of drivers becomes a major challenge for managers.

2. Website management

Website u-jek.blogspot.com is not managed properly. The information is not completed neither updated. The impression of carelessness in the website management shows the unpreparedness of the managers develop this venue. Managers need to designate specific people who specifically manage this website.

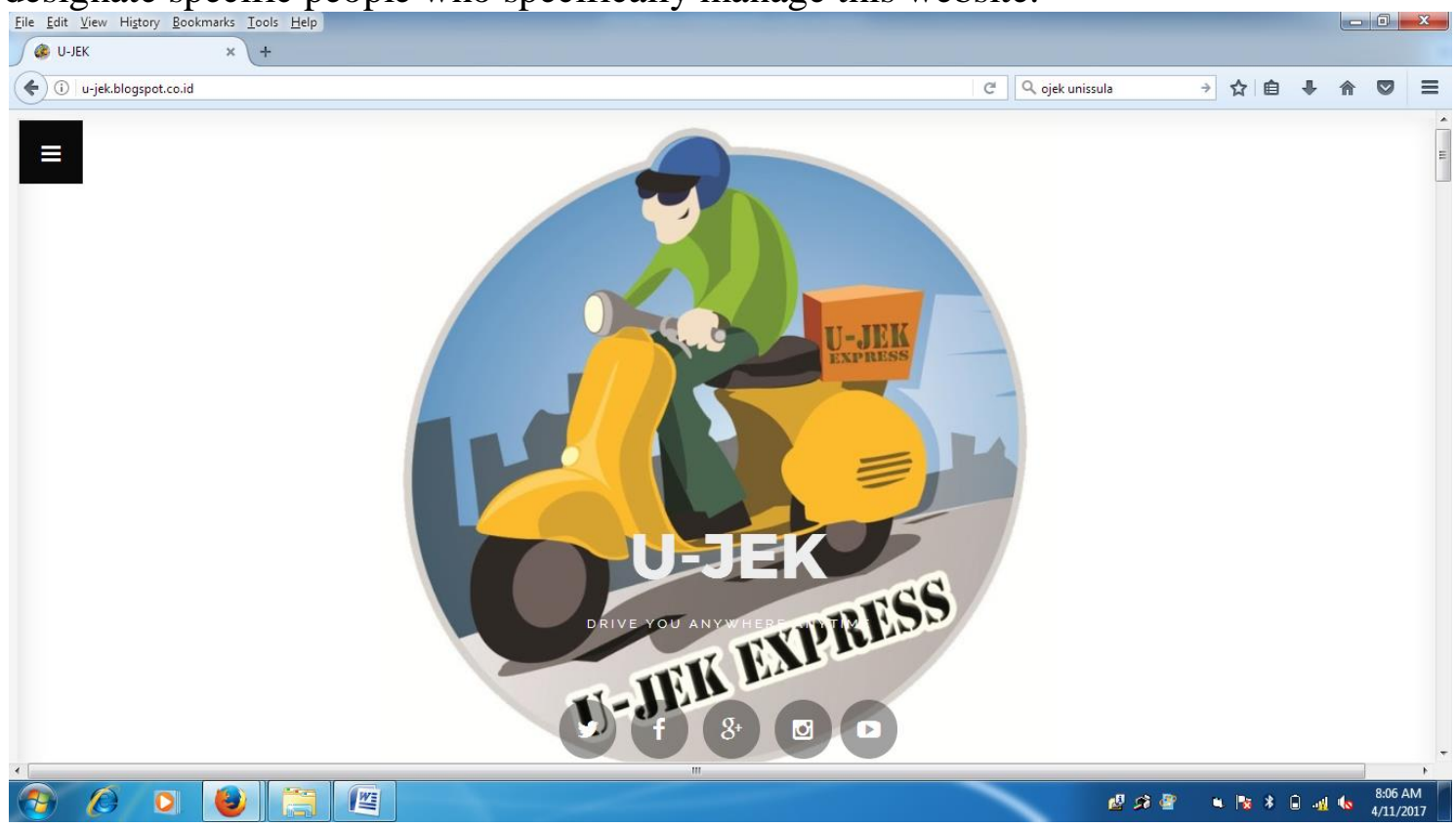

Figure 4. Website Display u-jek.blogspot.com

Website display from U-Jek with blogspot platform is not updated regularly. The information contained on this website has not been updated since it was created. This indicates rudimentary management.

3. Message Uniqueness

The uniqueness of the message has not appeared in the leaflet which is created by U-Jek manager. Messages are still flat and do not show the uniqueness of services provided by U-Jek managers. The uniqueness of the message is an advantage that can be utilized by U-Jek while it has not been used well by the manager of U-Jek until now. 


\section{Conclusion}

Management of U-Jek as an online taxibike (ojek) based student of syariah value has not been maximized due to give priority on slogan only. The biggest problem is the consistency of the driver. This internal issue must be resolved by U-Jek manager so that it can be a promotion in accordance with the availabe of communication infrastructure. Beside that, U-Jek has not been utilezed by endorsers from third parties to promote products and institutions. Supporters who act as a spokes person may come from lecturers, students, and employees. Managers can also request assistance from structural officials such as Rector, Dean, the Head of study program to promote U-Jek activities.

\section{Acknowledgement}

Appreciation and thanks the author gave to Unissula for funded this research. The completion of this article could be possible because of support from our college in Unissula. Special thank for all of you.

\section{References}

Denzin, N.K. \& Lincoln, Y.S. (2005). The SAGE Handbook of Qualitative Research, Third Edition. Thousand Oaks: SAGE Publications, Inc.

Kotler, P. (2000). Marketing Management: The Millenium Edition. USA: The Prentice Hall International.

Pudjosantosa, H. (2010). Handout Mata Kuliah, Strategi Komunikasi. Semarang: MIKOM Undip.

Pudjosantosa, H. (2010). Konsep dan Pengertian Manajemen Komunikasi, Handbook Mata Kuliah Komunikasi Strategis. Semarang: MIKOM Undip.

Saukko, P. (2003). Doing Research in Cultural Studies: An Introduction to Classical and New Methodological Approaches. London: Sage Publications, Inc. 